\title{
Multi-Aspect Research and Study of Territories Sustainable Development Management (on the Russia Example)
}

\author{
A. Sinitsyna*, O. Kuvekina \\ Moscow state University of Geodesy and Cartography (MIIGAiK), Moscow, Russia \\ ${ }^{*}$ Corresponding author. Email: anna_sinitsyna@bk.ru
}

\begin{abstract}
The most effective management of sustainable development of territories is currently relevant for the modern world community as a whole and for each country separately. The concept of sustainable development in Russia was adopted in 1996 and remains a priority to this day. We have come a long evolutionary path of managing sustainable development of territories from ecological components to a single complex of economic, environmental, social, political, transport, industrial, and other components. Russia has a powerful territorial potential and creation of an integrated model for managing the sustainable development of territories is an urgent and vital task of the country's life in the world community in modern conditions. At the Department of Economics of the Moscow State University of Geodesy and Cartography (MIIGAiK), a multi-element scientific and practical study of the complex socio-economic policy of Russia is being carried out. This stage includes a multi-aspect study and study of the management of sustainable development of territories in our country and development of recommendations and offers for optimizing an integrated management model for sustainable development of territories in Russia. The material is open information (regulations, publications, Internet resources, own studies).
\end{abstract}

Keywords: sustainable management of development of territories in Russia, the concept of sustainable development of Russia, prospects for sustainable management of development of territories in Russia, a model of management of sustainable development of territories, components of management of sustainable development of territories, multi-characteristics of territories in Russia.

\section{INTRODUCTION}

The concept of sustainable development in Russia was adopted in 1996 [1]. Four years after adoption in 1992 at the II World Conference on Environment and Development in Rio de Janeiro by representatives of 179 states of the Agenda 21 program, where the essence and goals of the Sustainable Development concept were considered [2]. At first, in Russia, the system of views on sustainable development focused on environmental aspects, but gradually an understanding came to the need to address economic, social and environmental issues within a single complex. Therefore, the essence of sustainable development has been significantly expanded, and currently the sustainable development model provides for harmonization of social, economic and environmental components, aimed at meeting the needs of both current and future generations. An important point is that for the sustainable development of the world economy, it is necessary to achieve this goal by each state [3]. Due to the vastness of its territories, Russia has fulfilled, is fulfilling and in the future will fulfill the world mission to solve socio-economic problems and preserve and increase a favorable environment and natural resource potential of the biosphere for present and future generations.

At the Department of Economics of the Moscow State University of Geodesy and Cartography (MIIGAiK), students, postgraduates and employees of the department conduct a comprehensive scientific and practical multiaspect research and study of the socio-economic policy of Russia. To date, the "green" stage of the study has been completed, namely, the consideration of modern problems of the Russian environment and the development of offers and recommendations for its sustainable development. The regulatory and legal relevance of the strategy for development of the natural 
potential of the Russian Federation has been studied; the main problems of "green" growth are highlighted; the directions of improving the efficiency of environmental policy were determined in the framework of scientific and practical research of the complex of socio-economic policy of Russia and the complex of property relations; offers and recommendations were developed [4]. The offer of this stage of the study is to identify and analyze the multidimensional components of sustainable development management of territories (on the example of Russia). Objectives: study and analysis of the management model for sustainable development of territories; definition and identification of multi-aspect model components; expert assessment of models in dynamics; development of offers and recommendations for optimizing the current model for managing sustainable development of territories (on the example of Russia).

\section{MATERIALS AND METHODS}

This paper is carried out using open and publicly available information (regulations, publications, Internet resources, own studies).

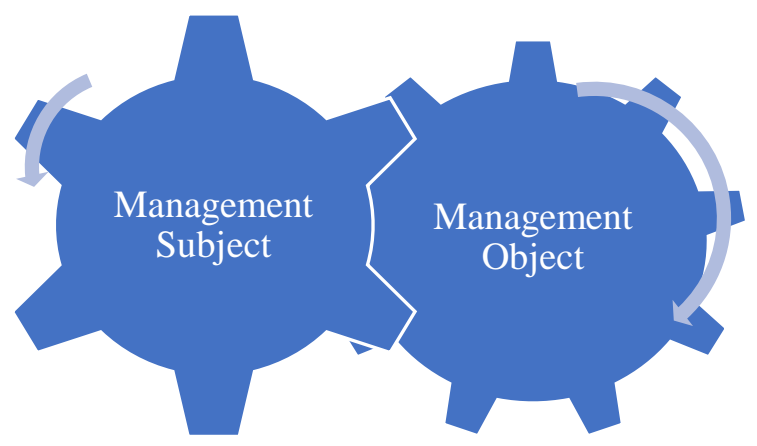

Figure 1 Management Subject and Management Object.

In the model of management of sustainable development of territories, it is possible to distinguish the subject of management and the object of management (Figure 1).

The object of management of sustainable development of territories is a set of economic entities and the population of a given territory. The subject of management is the corresponding authority and the governing bodies formed by it [5]. The main goal of the management model for sustainable development of territories is the most effective interaction of the SubjectObject Management system. For the purpose of assessing the effectiveness of the interaction of the Subject-Object of Control system, we have identified the multi-aspect components of the model (Table 1). Within the framework of the Subject of Management, the following is defined and allocated: development, infrastructure, planning, cooperation, legislation, government regulation, investments, foreign economic activity, innovations, and technologies. Within the Management
Object: economics, medicine, education, security, democracy, ecology, consumption, industry, infrastructure, and culture. Within the Subject-Object System: competitiveness, resource availability, industrialization, urbanization, infrastructure, cultural heritage, ecological tourism, and "green" biosphere. Then we made the ranking of the components (based on the unit total total weight of the components in the context of one model system). The data obtained for the Subject of Control system are provided in Figure 2.

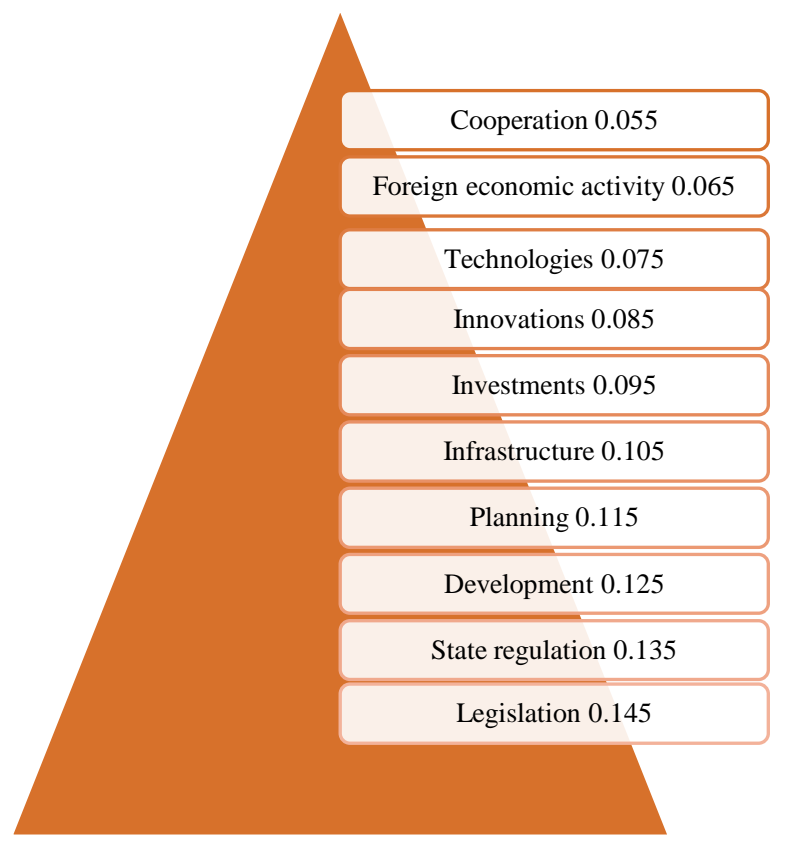

Figure 2 Ranking of system components. Management Subject.

The most essential and significant for the system of the Subject of Management is the "Legislation" component. This implies a competent operating regulatory framework, timely updates, additions and corrections, depending on the current situation with the development of territories. In Russia, the issues of a complex of property relations are relevant. The regulatory framework is in the process of formation and establishment. Therefore, it is necessary to monitor constantly the current changes in legislation and law [6]. The "Collaboration" component received the least weight. Unfortunately, today in Russia there is a strong unevenness in development of territories and the main emphasis is not on cooperation and interaction between the Subjects of Management and the territories under their jurisdiction, but on obtaining and deriving the maximum economic benefit from the current (available) potential for sustainable development of the territory.

For the Control Object system, the obtained ranking data are presented in Figure 3. 


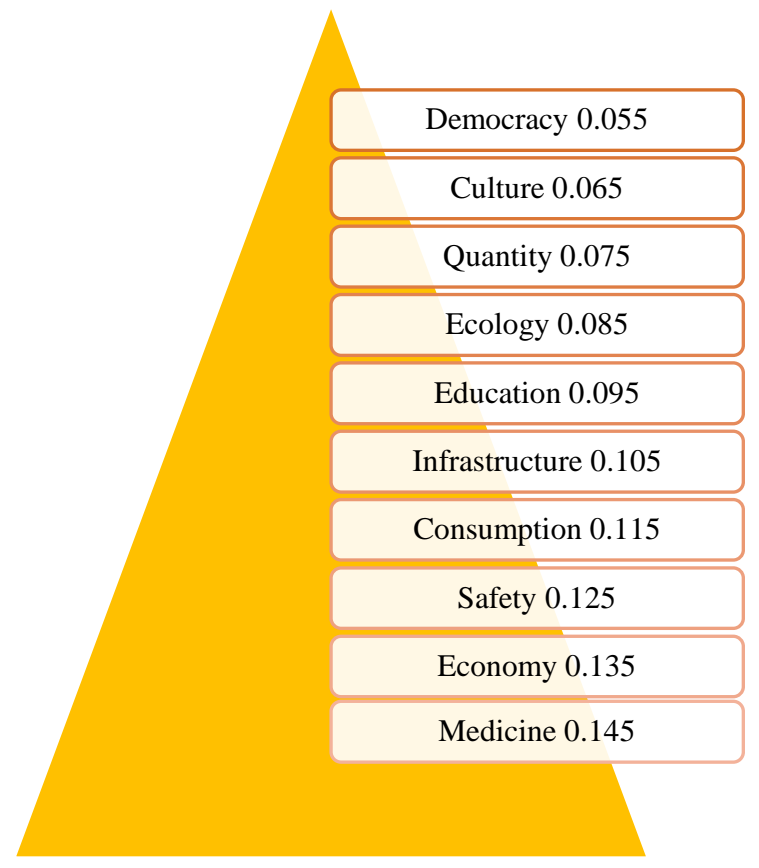

Figure 3 Ranking of system components. Control Object.

Interestingly, for the System, the Control Object at the moment is the "Medicine" component. Namely, the level of development of healthcare facilities, the availability of polyclinics, hospitals, pharmacies, diagnostic centers and ambulance services, the quality of medical services provided. Unfortunately, the simplest and most logical explanation is the current unstable epidemiological situation around the world. We singled out "Democracy" as the least significant component. At present, this is a component in the model of managing sustainable development of territories in the system of the Management Object is significantly inferior to "Security", "Consumption" and "Economy".

For the Subject-Object system, the ranking data is presented in Figure 4.

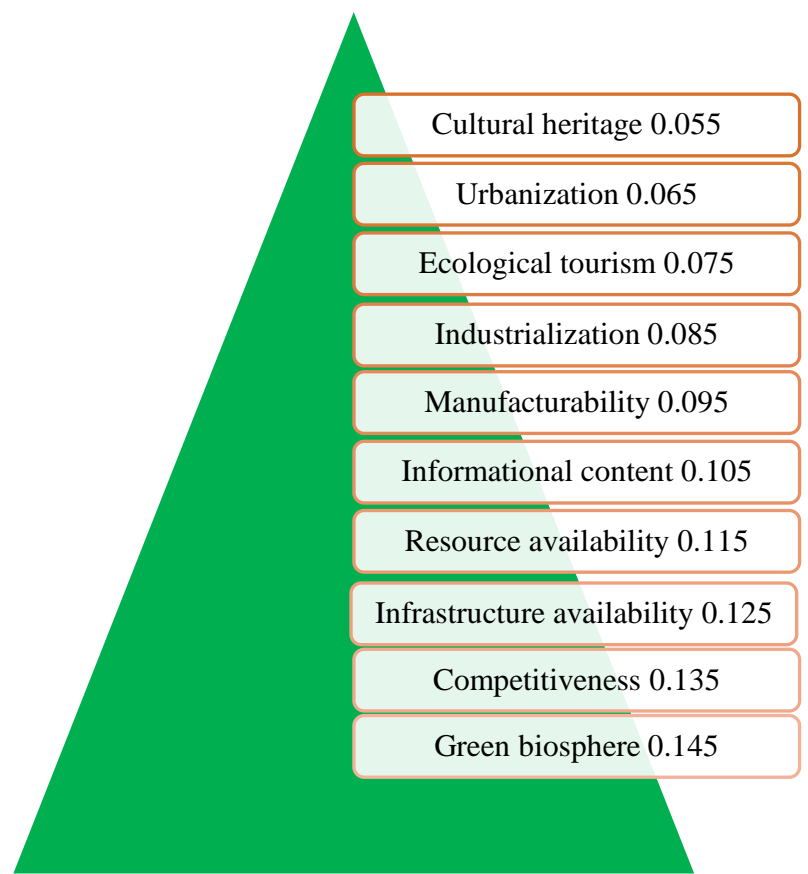

Figure 4 Ranking of system components of the SubjectObject System.

The international concept of sustainable development, as we can see from Figure 4, is effectively functioning and developing in the Russian Federation. The most significant component identified by our study is the "Green" biosphere. We have already realized that the biosphere is the basis of life on planet Earth, and not just a supplier of resources. An essential condition for the functioning of the socio-economic system in Russia shall be a system of stimulating human economic activity with the establishment of limits of responsibility for its environmental results. Russia, a territory where a significant part of pristine ecosystems is located, will soon, we hope, play a major role in harmonizing global issues of the "green" biosphere. The next stages will be formation of the predicted by V.I. Vernadsky sphere of mind (noosphere), when the spiritual values and knowledge of a Man living in harmony with the environment will become the center of national and individual wealth [7]. The least significant component of the Subject-Object System is "Cultural Heritage". In the Russian Federation at present the cultural and local

Table 1. Multidimensional components of the Sustainable Development Management model

\begin{tabular}{|l|l|l|}
\hline Management Subject & Management Object & Subject-Object System \\
\hline Development & Economy & Competitiveness \\
\hline Infrastructure & Medicine & Resource availability \\
\hline Planning & Education & Industrialization \\
\hline Cooperation & Safety & Urbanization \\
\hline Legislation & Democracy & Infrastructure \\
\hline Government regulation & Ecology & Manufacturability \\
\hline Investments & Consumption & Informational content \\
\hline Foreign economic activity & Industry & Cultural heritage \\
\hline Innovations & Infrastructure & Ecological tourism \\
\hline Technologies & Crop & "Green" biosphere \\
\hline
\end{tabular}


traditions and ways are significantly inferior in terms of the degree and development prospects of "resource availability", "technology", "information".

\section{RESULTS AND DISCUSSIONS}

According to the Constitution of the Russian Federation [8], Russia is a federal state and consists of 85 equal subjects of the Russian Federation (sometimes called simply "regions"), which are the main territorial unit specified in the Constitution and referring to all branches of government. Namely - 22 republics, 1 autonomous region, 4 autonomous districts, 9 territories, 46 regions, 3 federal cities (Moscow, St. Petersburg and Sevastopol). Each region of the Russian Federation has its own characteristics in terms of managing sustainable development of territories. We would like to note that in Russia for lands an important point is their classification and consideration of the legal status [9]. The assessment of 85 subjects of the Russian Federation is performed as part of a scientific and practical study of a complex of socio-economic policy of Russia in terms of managing sustainable development of territories (on example of Russia) on the basis of the components, considering their ranking according to the systems Subject of Management, Object of Management and System Subject-Object conducted by students, graduate students and employees of the Department of Economics of Moscow State University of Geodesy and Cartography. According to the previously described ten components for each system, an assessment of the management model for the sustainable development of Russian territories is carried out. The assessment is carried out on the basis of open information - State (national) reports on the state and use of land in the Russian Federation, prepared by the Ministry of Economic Development of the Russian Federation and the Federal Service for State Registration, Cadastre and Cartography of the Russian Federation (for 2005-2019) and the Forecast of long-term social economic development of the Russian Federation for the period up to 2030, developed by the Ministry of Economic Development of the Russian Federation [10].

For the assessment, we use indicators systematized and analyzed by components depending on the type of system of the sustainable development management model - the Management Subject System, the Management Object System, the Subject-Object System. Indicators are provided in Table 2. Based on these indicators, we assess the current model for managing sustainable development of territories (using the example of Russia). In the near future, according to the developed indicators and components, to assess the models of a number of foreign countries, then to conduct a comparative analysis of the results obtained in different countries and see how the world community is ready to gradually make the transition from sustainable development to intelligent development of territories, from the biosphere to the noosphere.

From the point of view of studying a model of managing sustainable development of territories, Russia is the most interesting object from the point of view of a huge territory, a large number of subjects of management (85), a high degree of pristine preservation of biosphere objects, multiculturalism, a wide range of manufacturability, information, infrastructure of territories (from almost undeveloped to ultra-modern highly developed science-intensive modern technologies). Therefore, the field for our scientific and practical research is vast, relevant and of great interest to our friendly team.

\section{CONCLUSION}

The modern problems of managing the sustainable development of territories are relevant, vital and rich in material for scientific and practical research. Our team of students, graduate students and teachers of the Department of Economics of the Moscow State University of Geodesy and Cartography will continue to study the model of managing sustainable development of territories (on the example of Russia). In the near future, and on the example of other countries. The plans are to conduct a comparative analysis, identify similar aspects, carefully study the differences and develop offers and recommendations for optimizing the management model for sustainable development of territories and approaching the model of reasonable management (from the biosphere to the noosphere).

\section{ACKNOWLEDGMENTS}

We would like to express our gratitude to colleagues from the Department of Economics, personally to the head of the Department of Economics - Doctor of Technical Sciences, prof., M.N. Zabaeva, Associate Professor, Candidate of Economic Sciences, O.A. Kuvekina (for fruitful cooperation and mutual assistance), employees of related departments, personally - to the Doctor of Engineering, prof. A.P. Sizov, students and postgraduates of the Moscow State University of Geodesy and Cartography for interesting joint research, support and mutual understanding.

Thanks to the Federal State Budgetary Educational Institution of Higher Education "Ural State Economic University" for the opportunity to take part in the II Conference on Sustainable Development: the Industrial Future of Territories. 
Table 2. Indicators of the components of the sustainable development management model (on the example of Russia)

\begin{tabular}{|c|c|}
\hline Component & Indicator \\
\hline \multicolumn{2}{|l|}{ Management Subject } \\
\hline Development & Social and economic development spending \\
\hline Infrastructure & Expenses for transport, energy, communications \\
\hline Planning & Availability of forecasts for short-term and long-term development \\
\hline Cooperation & Capital inflow rate \\
\hline Legislation & Expenses for legislative system formation \\
\hline State regulation & Budget spending, inflation, budget deficit \\
\hline Investments & Private and public investment levels \\
\hline Foreign economic activity & Balance of payments, import costs, export costs \\
\hline Innovations & Innovative renewal intensity \\
\hline Technologies & High tech spending \\
\hline \multicolumn{2}{|l|}{ Management Object } \\
\hline Economy & Gross Domestic Product (GDP), Gross National Income (GNI), Level of Income Differentiation \\
\hline Medicine & Health care costs \\
\hline Education & Education expenses \\
\hline Safety & Household and social security \\
\hline Democracy & Tatu Vanhanen Democratization Index \\
\hline Ecology & Environmental expenditures \\
\hline Consumption & Trade and service costs \\
\hline Number & Fertility, mortality, migration, emigration, \\
\hline Infrastructure & Transport, communications, energy costs \\
\hline Crop & Cultural spending \\
\hline \multicolumn{2}{|l|}{ Subject-Object System } \\
\hline Competitiveness & High-tech production facilities \\
\hline Resource availability & The level of natural resources by minerals \\
\hline Industrialization & The level of industrial production, knowledge-intensive and high-tech industries \\
\hline Urbanization & The level of development of agriculture, the number of megacities, the population in cities \\
\hline Infrastructure & The level of development of transport, communications, energy \\
\hline Manufacturability & Technology development level \\
\hline Informational content & Development of modern communications \\
\hline Cultural heritage & Level of development of local traditions \\
\hline Ecological tourism & Availability and degree of development of safe tourism \\
\hline "Green" biosphere & The level of environmentally friendly economic activity \\
\hline
\end{tabular}

\section{REFERENCES}

[1] The concept of the transition of the Russian Federation to sustainable development (Decree of the President of the Russian Federation No. 440 dated 01.04.1996). http://www.kremlin.ru/acts/bank/9120.

[2] V. Detsuk, Belarusian State University of Transport (BelSUT), Assessment of Damage from Environmental Pollution, 50 (2015) pp. 5.

[3] T.V. Uskova, Territories' sustainable development and modern management methods. In: Problems of Territory's Development, 2(106) (2020) pp. 7-18. DOI: https://doi.org/10.15838/ptd.2020.2.106.1.

[4] A. Sinitsyna, Russia's Natural Potential Sustainable Development and "Green" Growth Modern problems. In: IV International Scientific and Practical Conference "Sustainable Development and Green Growth on the Innovation Management Platform" (SDGG 2021), E3S Web Conf., 291 (2021), , p. 02016 DOI: https://doi.org/10.1051/e3sconf/202129102016

[5] L.S. Valinurova, L. . G. Akhtarieva, N.Z. Mazur, Territorial development management. Manual,Ufa:
BAGSU, 2012, p. 116. https://adminugra.ru/upload/medialibrary/0ad/upra vlenie-territorialnym-razvitiem.pdf .

[6] A.L. Sinitsyna, Topical issues of the state cadastral valuation of real estate objects. Management of land and property relations: materials of the XVI Intern. scientific-practical conf., November 18, 2020, Penza: PGUAS, 2020, p. 408.

[7] V.I. Vernadsky, Biosphere and noosphere, Science, 1989, p. 261 http://www.spsl.nsc.ru/win/nelbib/vernadsky.pdf.

[8] Constitution of the Russian Federation (Adopted by popular vote on December 12, 1993 with amendments approved during a nationwide vote on July 1 , 2020 . https://konstitutsiia.ru/konstitutsiia.pdf .

[9] A. Sizov, Eurasian Soil Science. Legal regulation of soil \& land protection in settlements of the Russian Federation, 9 (2010) p. 1402.

[10] Forecast of long-term socio-economic development of the Russian Federation for the period up to 2030 , developed by the Ministry of Economic Development of the Russian Federation. https://webmed.irkutsk.ru/doc/pdf/2030.pdf. 